DOI https://doi.org/10.30525/978-9934-26-038-4-12

\title{
MODERN APPROACHES OF CERVICAL INTRAEPITHELIAL NEOPLASIA TREATMENT WITH THE BACKGROUND OF GENITAL PAPILLOMAVIRUS INFECTION ASSOCIATED WITH TRICHOMONIASIS
}

\author{
Dyndar O. A. \\ Doctor of Medicine, Professor, \\ Professor at the Department of Obstetrics and Gynecology № 3 \\ Bogomolets National Medical University
}

Nykoniuk T. R.

Ph.D. in Medicine,

Associate Professor at the Department of Obstetrics and Gynecology № 3

Bogomolets National Medical University

Neimark O. S.

Ph. D. Student at the Department of Obstetrics and Gynecology № 3

Bogomolets National Medical University

Kyiv, Ukraine

Diseases of the cervix, caused by human papilloma virus (HPV), is one of the important medical and social problems in connection with the possibility of pathology of the cervix pathology development, among which benign diseases comprise $10-45 \%$, precancerous - 20-67\%, and with the untimely diagnosis increase the risk of the cervical cancer [6, p. 18], in particular more 95\% cervical cancer is associated with highly oncogenic HPV. In Ukraine cervical cancer ranks third among malignant neoplasms of the female genitalia, annually registered over 5 thousands of patients, detected for the first time [1, p. 33].

In cervical dysplasia pathogenesis, the dependence of HPV activity of highly oncogenic types remains insufficiently studied, which causes the development of cervical intraepithelial neoplasia (CIN), from the presence of cervical inflammatory process, in particularly caused by the Trichomonal infection. The role of the inflammatory process on the mechanism of HPV penetration into the basal layer is investigated, with subsequent violation of the stratification of the multilayered epithelium of the cervix [3, p. 20]. In the practical gynecology, there is no consensus on the tactics of management of women initiated by HPV and acquired CIN of the cervix in combination with other genital infections. In the majority of cases you have to choose 
between surgical and conservative treatment, including the use of drugs of different therapeutic groups [4, p. 49].

Flow analysis of methods of diagnosis and treatment of inflammatory processes of the genitals, caused Tr. Vaginalis, identified certain aspects of the problem: there is an increase in resistance to antiprotozoal drugs, the properties of the pathogen have changed significantly, requiring a revision of the standards for the diagnosis and treatment of genital Trichomonal infection. Recently, new scientific studies of physiological and pathological biological films structure have appeared, their role in the persistence and recurrence of inflammatory diseases [2, p. 41; 5, p. 114], indicating the need to develop new effective treatments for CIN, associated with HPV on the background of Trichomonal infection. Treatment of the Trichomonal infection with the use of ultrasonic cavitation with the aim of destruction of the pathological biological film in combination with the antiprotozoal therapy, in our opinion, will quickly and reliably relieve patient from inflammation caused by Trichomonal infection, will help reduce the viral load, thereby improving the effectiveness of CIN treatment and reducing the likelihood of developing cervical cancer.

In order to increase efficiency treatment of CIN on the background of HPV associated with trichomoniasis, by applying complex antiprotozoal therapy using the method of ultrasonic cavitation, 133 women of reproductive age were examined with the cervical pathology on the background of HPV associated with trichomoniasis (main group): 33 (24.8\%) with PAP smear results ASCUS, 77 (57.9\%) with LSiL (CIN I), 23 (17.3\%) with HSiL (CIN II), HPV persistence and identified Tr. Vaginalis received combined cyclic antiprotozoal therapy with 5-nitroimidazole to $2500 \mathrm{mg}$ per day for 3 days with an interval of 6 days, due to the development of Tr. Vaginalis life cycle. In order to destroy the pathological biological film before each cycle of antiprotozoal therapy there was a session of ultrasonic cavitation using the device AUZH-100-01 «Fotek», solution 5-nitroimidazole (5 mg/ml, 100ml), exposure time 1-2 min. The comparison group was formed of 67 women, of which of 17 (25.4\%) detected ASCUS, in 41 (61.2\%) LSiL (CIN I), in 9 (13.4\%) - HSiL (CIN II), undergoing cyclic antiprotozoal monotherapy without the usage of ultrasonic cavitation. All patients were examined and treated at the clinical bases of the Department of Obstetrics and Gynecology № 3 Bogomolets NMU and in the clinic «PROFIMED» (Kyiv, Ukraine). Examination of women included cytology (PAP smear) and cultural detection using selective environment In Pouch TV and In Trey GC to detect Tr. Vaginalis, polymerase-chain reaction (PCR) with HPV genotyping Real Time and determining the viral load. The effectiveness of genital trichomoniasis treatment was evaluated after 3 months; PAP smear and HPV viral load after 12 months after the end of therapy. Statistical processing of the 
obtained data was carried out with the help of the statistical analysis programs (Stastica for Windows v.7.0, Microsoft Excel).

All female patients were representative by age, history and concomitant gynecological pathology. DNA genotyping analysis of 19 highly oncogenic HPV types in the main $(39.8 \%)$ and comparative (38.8\%) groups revealed a predominance of HPV 16 types. 18 (24.8\% and 22.4\%) and 31 (16.5\% and $16.4 \%$ ) types of HPV were also more common. As a result of the study in the main group it was additionally determined: HPV 56 in 9\%, HPV 35, HPV 39, HPV 51, HPV 58, HPV 59 in 5.3\% of observations. In the comparison group, HPV 58 occurred in 13.4\%, HPV 33 in 8.9\%, HPV 51 in 5.9\% of cases. It should be noted that in $56.5 \%$ of our respondents we found one, in $23.5 \%$ - two, in $16 \%$ - three, and in some cases (4\%) - four types of viruses $(\mathrm{p}<0.05)$. In the quantitative determination of HPV in patients of the main and comparison groups was determined by the viral load, which exceeded the threshold of clinical significance in 52.6\% and 53.8\%.

After completing the stages of the survey, patients of the main group underwent complex antiprotozoal therapy with an emphasis on the destruction of pathological biological film using the method of ultrasonic cavitation in an outpatient setting. Women comparison group - antiprotozoal monotherapy without destruction of the pathological biological film.

Comparing the results of the Trichomonal infection treatment in both groups observed through 3 months after the end of therapy, we received objective data, confirming its effectiveness. In the main and comparison groups the number of the cured patients amounted to $127(95.5 \%)$ and $49(73.1 \%)$, relapses were diagnosed in $6(4.5 \%)$ and $18(26.9 \%)$ respondents, according to the observation groups. Therefore, in the main group of women the method of complex therapy with ultrasonic cavitation was more effective almost in 6 times than traditional methods within existing clinical protocols $(\mathrm{p}<0.05)$.

Retest's results, conducted 12 months after the end of our proposed therapy for genital trichomoniasis, prove a decrease in the number of highly oncogenic types of HPV, as well as viral load in patients of both groups. But in the main group of women the effectiveness of therapy was in 5.3 times higher $(\mathrm{p}<0.05)$ than in patients of the comparison group, especially with regard to the level of HPV viral load more than $6.5 \mathrm{Lg}$.

Analysis of PAP smear results 12 months after the antiprotozoal therapy indicates an improvement in the cytological results of the PAP smear and colposcopic picture. In particular, from both groups of observation the group of women was defined (45.5\%) with the results of the PAP smear NILM. It is important to reduce the number of patients to isolated cases $(2.5 \%)$ with the results of the PAP test ASCUS, as well as regression of cervical CIN, which was manifested by a decrease in the percentage of patients with PAP 
smear results LSiL (CIN I) with $59 \%$ to $32 \%(\mathrm{p}<0.05)$. At the same time, from $32(16 \%)$ respondents from both groups with a previous PAP test value HSiL by 12 months left after therapy 26 (13\%), which can be stated as statistically insignificant, however, positive changes $(p>0.05)$.

Therefore, complex method of treatment of Trichomonal infection using ultrasonic cavitation has proven its effectiveness in $95.5 \%$ patients and allowed to reduce the number of recurrences of the disease in 5.9 times, contributed to the reduction of 5.3 times the number of cases of detection of highly oncogenic types of HPV, as well as viral load in women with CIN on the background of HPV associated with Tr. Vaginalis, allowed to normalize cytological parameters in $57.9 \%$ women, contributed to the regression of moderate to the mild cervical dysplasia in $17.4 \%$ cases.

\section{References:}

1. Борис Е.Н., Гервазюк О.И. Анализ результатов всеукраинского исследования применения препарата Лаферомакс в комплексной терапии урогенитальных инфекций и патологии шейки матки у женщин различного возраста. Здоровье женщины, 2016. № 9. С. 33-39.

2. Диндар О.А., Никонюк Т.Р., Неймарк О.С. Використання ультразвукової кавітації для лікування цервікальної інтраепітеліальної неоплазії на тлі генітальної папіломавірусної інфекції асоційованої з трихомоніазом. Збірник наукових праџь Асочіаџї акушерів-гінекологів Украӥни, 2020. № 2. С. 41-48.

3. Манжура Е.П. Цервикальная интраэпителиальная неоплазия (CIN). Современные подходы к диагностике, лечению и реабилитации. Здоровье женщины, 2016. № 5. С. 19-25.

4. Камінський В.В., Суханова А.А., Шалько М.Н. Порівняльна оцінка результативності різних схем застосування природних флавоноїдів Протефлазіду у терапії цервікальних інтраепітеліальних неоплазій (CIN) легкого по помірного ступеня, асоційованих 3 генітальною папіломавірусною інфекцією. Здоровье женщины, 2019. № 1. C. $48-54$.

5. Свидсински А., Мендлинг В., Лонинг - Баук В. Персистенция биопленок Gardnerella Vaginalis на вагинальном эпителии после стандартной терапии пероральным метронидазолом. Здоровье женщины, 2016. № 9. C. 112-114.

6. Dyndar O., Nykoniuk T., Neimark O. Risk factors of pre-cancer cervical diseases in women of reproductive age. Medical Science of Ukraine, 2020. Vol. 16. № 1. P. 17-21. 